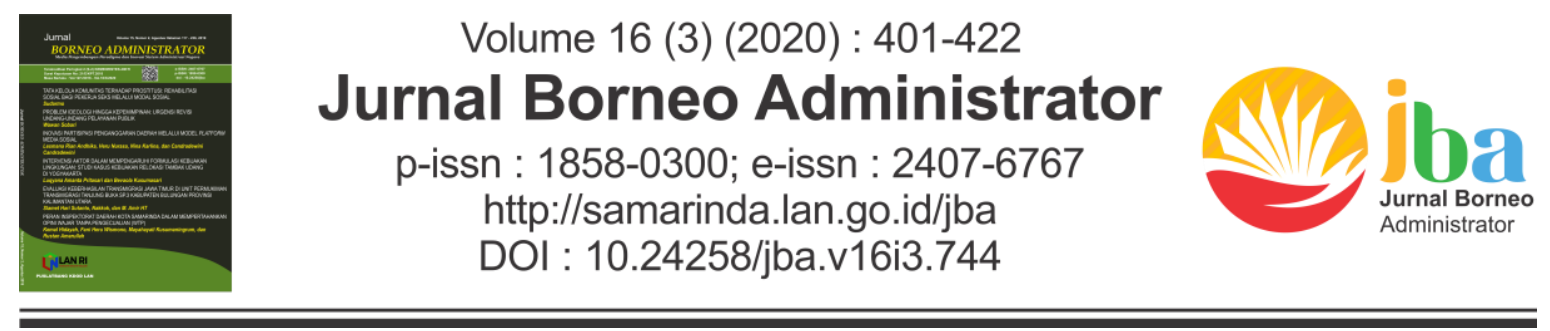

\title{
PENERAPAN KEBIJAKAN SISTEM MERIT: PRAKTIK TERBAIK DI LEMBAGA ADMINISTRASI NEGARA
}

\section{IMPLEMENTATION OF MERIT SYSTEM POLICY: BEST PRACTICE IN NATIONAL INSTITUTE OF PUBLIC ADMINISTRATION}

\author{
Adi Suryanto ${ }^{a}$ dan Mariman Darto ${ }^{b}$ \\ a Lembaga Administrasi Negara, Jl. Veteran 10 Jakarta, aditgsar@gmail.com \\ b Puslatbang KDOD, Jl. HM. Ardans (Ring Road III) Samarinda, \\ email: marimandarto@gmail.com
}

Naskah diterima: 28 Juli 2020; revisi terakhir: 11 November 2020; disetujui: 18 Desember 2020

How to Cite: Suryanto, Adi dan Darto, Mariman. (2020). Penerapan Kebijakan Sistem Merit: Praktik Terbaik di Lembaga Administrasi Negara. Jurnal Borneo Administrator, 16 (3), 401-422. https://doi.org/10.24258/jba.v16i3.744

\begin{abstract}
The implementation of the merit system policy in National Institute of Public Administration (NIPA) since 2015 has recently gained a positive recognition. In 2019, NIPA has got an excellent rating in the Merit System Index published by the Commission of State Civil Apparatus (KASN). The purpose of this research is to explore NIPA's experience in implementing the merit system processes, what has been done and how to do it. Through an explorative-qualitative approach, data were collected by interviewing key informants as well as document analysis of the merit system implementation process for the last 5 years (2015-2020) and using participation observer technique. The result showed that NIPA has consistently implemented the merit system according to its principles and regulation during its implementation. It is also found that top leaders' commitment has played a dominant and significant factor in the successful merit system implementation.
\end{abstract}

Keywords: Merit System, Civil Servant, Professionalism

\begin{abstract}
Abstrak
Sistem merit yang diterapkan di Lembaga Administrasi Negara (LAN) sejak tahun 2015 lalu telah mendapatkan pengakuan dari Pemerintah. Pada tahun 2019 LAN meraih predikat sangat baik dalam penilaian Indeks Sistem Merit (Merit System Index) yang dilakukan oleh Komisi Aparatur Sipil Negara (KASN). Tujuan penelitian ini adalah untuk mengekplorasi lebih jauh tentang mengapa LAN menerapkan sistem merit, apa saja yang telah dilakukan, dan bagaimana melakukannya. Dengan menggunakan pendekatan kualitatif-eksploratif, pengumpulan berbagai data/informasi pendukung sejak diterapkannya sistem merit (2015-2020), wawancara terbatas dengan para pengambil kebijakan dilakukan dan menggunakan teknik participation observer.
\end{abstract}


Hasilnya bahwa penerapan sistem merit di LAN dilakukan sesuai dengan prinsip dan tahapan kebijakan yang ada. Komitmen pimpinan dan konsistensi dalam penerapan kebijakan sistem merit menjadi faktor determinan.

Kata Kunci: Sistem Merit, Pegawai Negeri Sipil, Profesionalisme

\section{A. PENDAHULUAN}

Tantangan seabad Indonesia merdeka, 2045 bukan tantangan mudah. Pada saat itu Produk Domestik Bruto Indonesia (PDB) perkapita Indonesia diprediksi mencapai US\$ 23.199. Indonesia diperkirakan masuk dalam klaster Negara Maju dengan PDB terbesar kelima di dunia yakni US\$ 7,4 triliun. Ketimpangan antarwilayah diperkirakan terkurangi. Peranan Kawasan Timur Indonesia, yang sebelumnya berkontribusi minimal terhadap pertumbuhan ekonomi, meningkat drastis hingga mencapai 25\% (Presiden Republik Indonesia, 2020:19).

Tata kelola pemerintahan yang baik menjamin peningkatan investasi yang secara tidak langsung meningkatkan pertumbuhan ekonomi. Sebaliknya, pengelolaan pemerintahan yang buruk, yang ditunjukkan oleh korupsi, kolusi dan nepotisme (KKN), berpengaruh terhadap penurunan tingkat investasi, menurunkan produktifitas belanja publik, mendistorsi alokasi sumber daya dan pada akhirnya berimbas pada terhambatnya pertumbuhan ekonomi (Lutfi et al., 2020). Penerapan tata kelola pemerintahan yang baik, yang salah satunya melalui penerapan sistem merit dalam merekrut pejabat tingginya, dapat memecahkan berbagai permasalahan ketidakefisienan (smashed the in efficiency) sistem administrasi negara yang lama, dimana korupsi dan nepotisme terjadi (Davis, 2006). Merit system sebagai salah satu bentuk reformasi kepegawaian berkorelasi terhadap kualitas birokrasi dalam suatu negara, sekaligus merupakan syarat mutlak untuk menjamin tata kelola pemerintahan yang profesional (Prasojo, 2010; Ismail, 2019; Stancetik, 2020).

Tata kelola pemerintahan yang bersih, efektif dan terpercaya merupakan misi presiden Joko Widodo. Misi ini untuk mewujudkan Indonesia maju yang berdaulat, mandiri dan berkepribadian berlandaskan gotong royong adalah tepat. Misi tersebut menjadi landasan utama pemerintah untuk meningkatkan kualitas pelayanan publik. Presiden menetapkan lima arahan utama sebagai strategi pencapaian misi pemerintah tersebut (Presiden Republik Indonesia, 2020:20), sebagai berikut : pertama, pembangunan SDM pekerja keras yang dinamis, produktif, terampil, menguasai ilmu pengetahuan dan teknologi didukung dengan kerja sama industri dan talenta global. Kedua, melanjutkan pembangunan infrastruktur untuk menghubungkan kawasan produksi dengan kawasan distribusi, memudahkan akses ke kawasan wisata, mendongkrak lapangan kerja baru, dan mempercepat peningkatan nilai tambah perekonomian rakyat. Ketiga, menyederhanakan segala bentuk regulasi dengan pendekatan Omnibus Law, terutama menerbitkan dua kebijakan nasional: Undang-Undang Cipta Lapangan Kerja dan Undang-Undang Pemberdayaan Usaha Kecil Menengah dan Koperasi (UKMK). Keempat, memprioritaskan investasi untuk penciptaan lapangan kerja, memangkas prosedur dan birokrasi yang panjang, dan menyederhanakan eselonisasi. Kelima, melakukan transformasi ekonomi dari ketergantungan SDA menjadi daya saing manufaktur dan jasa modern yang memiliki nilai tambah tinggi bagi kemakmuran bangsa demi keadilan sosial bagi seluruh rakyat Indonesia.

Pemerintah menghadapi tantangan yang tidak mudah lima tahun ke depan. Setidaknya ada empat tantangan dalam lima tahun ke depan yang perlu diperhatikan (Presiden Republik Indonesia, 2020:257-258), Pertama, terkait dengan profesionalitas ASN. Data Komisi Aparatur Sipil Negara (KASN) menunjukkan bahwa dari 34 Kementerian, baru 6 Kementerian yang menerapkan sistem merit dengan sangat baik. Proses pengambilan 
keputusan juga tidak efisien karena panjangnya hierarki eselonisasi. Dari sisi kompetensi, jumlah tenaga spesialis di lingkungan ASN masih kurang, serta rendahnya kompetensi dan tingkat pendidikan ASN, terutama di luar Jawa. Dari sisi distribusi, persebaran ASN dengan keahlian tertentu/fungsional belum berbasiskan sektor unggulan kewilayahan juga belum merata. Belum lagi intervensi politik terutama dari kepala daerah dalam pengelolaan kepegawaian.

Kedua, dari aspek kelembagaan, masih terdapat tumpang tindih tugas dan fungsi antarlembaga pemerintah pusat (Kementerian, Lembaga Pemerintah Non Kementerian (LPNK), Lembaga Non Struktural (LNS). Tumpang tindih tersebut disebabkan oleh belum adanya penataan tugas dan fungsi dari lembaga-lembaga tersebut. Fragmentasi tugas dan fungsi tersebut mempersulit pola koordinasi antarlembaga sehingga tata kelola menjadi tidak efektif.

Ketiga, pada aspek pelayanan publik, data Ombudsman RI menunjukkan bahwa jumlah pengaduan masyarakat meningkat signifikan dari 6.859 di tahun 2015 menjadi 8.314 pada tahun 2018, mayoritas pengaduan terkait penundaan berlarut dan penyimpangan prosedur.

Keempat, dari sisi akuntabilitas, data Badan Pemeriksa Keuangan (BPK) tahun 2018 menunjukkan masih terdapat permasalahan sistem pengendalian internal dan ketidakpatuhan terhadap ketentuan peraturan perundang-undangan dan praktik korupsi.

Persoalan mendesak yang perlu penyelesaian secara cepat adalah terkait dengan persoalan pertama, profesionalitas ASN. Persoalan ini masuk sebagai prioritas pertama presiden dalam Rencana Pembangunan Jangka Menengah Nasional 2020-2024, khususnya dalam mendukung percepatan transformasi ekonomi melalui peningkatan pelayanan publik. Salah satu faktor pengungkit profesionalitas ASN adalah kebijakan sistem merit.

Keberadaan sistem merit sangat penting bagi manajemen ASN. Undang Undang Nomor 5 Tahun 2014 Tentang Aparatur Sipil Negara, Pasal 51 menyatakan bahwa manajemen ASN diselenggarakan berdasakan sistem merit. Sistem merit adalah kebijakan dan manajemen ASN berdasarkan pada kualifikasi, kompetensi, dan kinerja secara adil dan wajar tanpa membedakan faktor politik, ras, agama, asal usul, jenis kelamin, dan kondisi kecacatan. Ini berarti keseluruhan aspek dalam manajemen ASN, mulai dari aspek perencanaan ASN hingga pemberhentiannya didasarkan atas sistem merit.

Hasil kajian Komisi Aparatur Sipil Negara (KASN), sampai saat ini hanya 6 Kementerian/Lembaga Non Kementerian (K/L) yang masuk kategori baik dan sangat baik. Keenam K/L tersebut adalah Kementerian Keuangan (kategori IV/sangat baik), Kementerian BUMN (kategori IV/sangat baik), Kementerian PUPR (kategori IV/sangat baik), Kementerian Kelautan dan Perikanan (kategori IV/sangat baik), Lembaga Administrasi Negara (kategori IV/sangat baik) dan Badan Pengawasan Keuangan dan Pembangunan (kategori III/baik) (KASN, 2018:14).

Data ini mengonfirmasi bahwa kebijakan reformasi birokrasi dan tata kelola pemerintahan yang baik, masih menghadapi tantangan dan kendala yang tidak mudah. Profesionalisme ASN yang diharapkan sebagai penggerak utama dalam mewujudkan citacita bangsa dan tujuan negara, masih belum berfungsi normal. Meskipun demikian, pemerintah dalam lima tahun ke depan menargetkan K/L masuk dalam kategori III/baik sebanyak 100\%, sedangkan provinsi 85\% (Presiden Republik Indonesia, 2020:261). Optimisme pemerintah dalam pencapaian indeks sistem merit ini menunjukkan kesiapan pemerintah dalam menghadapi tantangan dan kendala dalam mengakselerasi profesionalisme ASN. 
LAN termasuk Lembaga Pemerintah Non Kementerian (LPNK) yang terbaik dalam menerapkan sistem merit. Penelitian ini bertujuan untuk mengungkap best practices yang dilakukan LAN dalam penerapan sistem merit ini. Pertanyaan yang ingin dijawab dalam penelitian ini adalah: Apa yang dilakukan LAN? Mengapa LAN melakukannya? dan Bagaimana LAN melakukan sistem merit?

\section{B. METODE PENELITIAN}

Penelitian ini menggunakan metode kualitatif-eksploratif dengan satu lokus di LAN. Jika dilihat dari karakteristiknya, penelitian ini termasuk jenis penelitian studi kasus (case study). Teknik pengumpulan data/informasi dilakukan melalui tiga cara yakni: pertama, mengumpulkan berbagai data/informasi berupa berbagai laporan kegiatan terkait penerapan sistem merit sejak perencanaan, pelaksanaan, dan evaluasinya selama kurun waktu 20152020; kedua, melakukan wawancara terbatas dan mendalam (indepth interview) dengan berbagai narasumber para pengambil kebijakan terkait di LAN; dan ketiga, melakukan participation observer yakni terlibat dan menjadi bagian dari proses, sehingga menemukan pengalaman yang berharga secara utuh dalam penerapan sistem merit (Dwiyanto, 2016:36).

Penelitian ini bertujuan untuk mengungkap best practices yang dilakukan LAN dalam penerapan sistem merit ini. Pertanyaan yang ingin dijawab dalam penelitian ini adalah: Apa yang dilakukan LAN? Mengapa LAN melakukannya? dan Bagaimana LAN melakukan sistem merit?

Penelitian studi kasus ini digunakan untuk mengeksplorasi data/informasi, memperdalam pengetahuan, dan mencari ide-ide baru mengenai suatu gejala tertentu, menggambarkan fenomena sosial yang berkembang, dan menjelaskan bagaimana terjadinya suatu fenomena sosial untuk merumuskan masalah secara terperinci (Mudjiyanto, 2018). Penelitian terhadap fenomena empiris dan kontekstual dalam suatu obyek penelitian tertentu akan memperkaya atau memperbanyak variabel menarik yang dapat ditemukan. Inilah karakter studi kasus dalam sebuah penelitian. Berbagai fenomena itu jika dieksplorasi lebih dalam akan memandu penyelesaian masalah penelitian yang diangkat oleh peneliti (Dul \& Hak, 2008:4).

\section{KERANGKA TEORI}

Sejarah penerapan sistem merit telah berumur panjang. Menurut Miftah Thoha (2018) sistem ini mulai diterapkan sejak zaman Dinasti Qin dan Han di China. Dinasti ini mengenalkan sistem merit melalui sistem pendidikan dan pelatihan, diikuti dengan ujian dan seleksi bagi calon-calon pejabat pemerintahan. Dalam upaya melaksanakan kekuasaan kerajaan yang wilayahnya begitu luas, besar, dan menyebar, pemerintahan Dinasti Qin dan Han menghadapi ruwetnya jaringan jabatan yang kompleks (Thoha, M, 2018).

Tuntutan penerapan sistem merit dipicu oleh berbagai latar belakang. Pertama, korupsi, kolusi dan nepotisme (KKN). Beberapa kajian empirik menunjukkan bahwa masalah KKN menjadi pemicu lahirnya kebijakan ini (Davis, 2006). Semangat mengurangi korupsi melalui penerapan sistem merit memungkinkan sebuah organisasi mendapatkan profil pimpinan yang lebih baik (Dahlström, Lapuente, \& Teoreti, 2012, Stancetik, 2020).

Kedua, latar belakang politik juga menjadi alasan kuat kenapa sistem merit penting diterapkan (Dahlström, Lapuente, and Teoreti, 2012). Fabian Tract (1964) mengatakan bahwa tidak ada alasan yang dapat dibenarkan bahwa jabatan administrator harus dikaitkan dengan kepentingan politik (Davis, 2006). Selengkapnya, Fabian Tract mengatakan: 
"There is no provision for new appointments from outside when governments change. The administrator is supposed to be apolitical, and yet equally good at helping to devise and advocate socialist, liberal or conservative policies and capable of switching wholeheartedly from one to the other at any time of life. The importance of his being able to do so increases with seniority and age, whereas his ability to do so is likely to decline."

Di Amerika Serikat (AS) misalnya, konsep sistem merit lahir sebagai respon atas praktik "spoil-system" dalam manajemen pegawai pemerintah (Federal Civil Service). Spoil system merupakan praktik merekrut pegawai pemerintah yang didasarkan atas balas jasa pemerintah atas dukungan pegawai saat kampanye pemilihan presiden. Sebagaimana diketahui, sejak awal pemerintahan hingga awal tahun 1880, kualitas pegawai pemerintah sangat buruk. Tidak ada standar dalam rekrutmen, pengembangan karier mereka, apalagi dalam penempatan mereka di satu jabatan tertentu. Seiring waktu, praktik ini berkontribusi pada tenaga kerja yang tidak memiliki kualifikasi yang diperlukan untuk melakukan pekerjaannya, yang pada gilirannya berdampak buruk pada efisiensi dan efektivitas pemerintah dan kemampuannya dalam melayani rakyat Amerika. Namun dalam perkembangannya, sistem merit diterapkan dengan penuh komitmen dengan tetap menjaga profesionalisme dan netralitas. Keberadaan United States Merit System Protection Board sangat menentukan dalam menjaga standar, prinsip dan kebijakan perlindungan terhadap sistem merit (USMSPB, 2020:1).

Ketiga, pertimbangan inefisiensi yang terjadi pada sistem administrasi negara yang lama. Sistem merit dapat memecahkan ketidakefisienan (smashed the inefficiency) yang terjadi pada penerapan sistem administrasi negara yang lama, dimana korupsi dan nepotisme terjadi. Sistem rekrutmen yang lebih modern (sistem merit) memungkinkan sosok pimpinan bertindak efisien, penuh prestasi dan memberikan pelayanan yang berbiaya murah (Davis, 2006, Dwiputrianti, 2018).

Keempat, pertimbangan profesionalisme menjadi alasan paling rasional. Jon Davis sebagaimana mengutip Fabian Tract (1964) mengatakan bahwa merekrut pegawai dengan kemampuan dan kompetensi unggul lebih penting dan bermanfaat bagi organisasi dari pada pilihan dan pertimbangan senioritas dan usia. Seiring dengan waktu, senioritas atau batasan usia mengalami penurunan kemampuan yang berdampak pada penurunan produktifitas (Davis, 2006). Meritokrasi melahirkan kualitas birokrasi yang lebih modern, bukan sebaliknya merusak karena lambatnya respon dan keteapan dalam pelayanan publik. Birokrasi yang profesional menjadi karakteristik meritokrasi yang dengan pertimbangan rasionalitas - bukan sebaliknya kepatuhan "buta" ("blind" adherence) terhadap kebijakan pemerintah. Dengan demikian, evaluasi dan memberikan feedback terhadap kebijakan dapat dilakukan secara terus menerus sebagai cara untuk memberikan kemanfaatan bagi publik khususnya dalam pelayanan publik (Andersen, 2018, Wijaya dkk, 2019). Menurut Baimenov dan Phillips (2015:15) tingkat meritokrasi yang tinggi akan meningkatkan kualitas pemerintahan termasuk memberikan dampak pada penurunan korupsi dan peningkatkan kualitas penggunaan sumber daya negara secara efisien.

Sementara itu, Silberman (1993) yang dikutip oleh Carl Dahlström, Victor Lapuente, and Jan Teoreti (2012), mengatakan bahwa profesionalisme dipandang sebagai salah satu karakteristik penting dalam sistem merit, khususnya dalam birokrasi pemerintahan. Dalam penelitian yang menganalisis data original mengenai postur birokrasi dan efeknya terhadap korupsi di 52 negara, Carl Dahlström, Victor Lapuente, and Jan Teoreti (2012), juga membedakan antara birokrasi yang berorientasi pada kelembagaan/organisasi dengan 
birokrasi yang orientasinya profesional. Birokrasi profesional memiliki spirit untuk mengurangi korupsi, tidak sekedar memilih orang yang yang lebih kompeten. Namun, dengan proses rekrutmen berbasis sistem merit, profil SDM yang direkrut, kepentingan politik dan profesionalitas calon dapat diketahui secara lengkap (Dahlström, Lapuente, \& Teoreti, 2012; Meyrina, 2016).

Young (2008) dalam Ora-orn Poocharoen and Alex Brillantes (2013) yang menganalisis definisi dan instrumen sistem merit di Asia dibandingkan dengan di Amerika Serikat mengatakan bahwa meritokrasi digambarkan sebagai konsep yang memadukan antara kecerdasan/intelektualitas (intelligence) dengan tindakan. Karena itu, meritokrasi dianggap sebagai keunggulan birokrasi sektor publik yang lebih modern, dimana sektor publik dipandang sebagai tempat yang layak bagi banyak profesi (Poocharoen \& Brillantes, 2013).

Kelima, menciptakan budaya persaingan yang kompetitif untuk mendapatkan kualitas pegawai yang memenuhi kualifikasi, kompetensi dan prestasi. Rekrutmen terhadap pegawai negeri yang kompetitif telah menjadi metode perekrutan pegawai negeri sipil selama ribuan tahun dan dianggap sebagai landasan sistem merit (Johnson \& Lewis, 2018).

Northcote dan Trevelyan (1854) mengatakan bahwa sistem merit dalam rekrutmen dan promosi, secara prinsip diterapkan untuk mendukung pengembangan kapasitas dan kapabilitas SDM dalam peningkatan kinerja organisasi. Karena itu, setiap organisasi publik perlu mendesain proses rekrutmen secara kompetitif dan terbuka dan mempromosikannya sesuai dengan prestasi kerja bukan karena senioritasnya (Poocharoen \& Brillantes, 2013).

Keenam, karena sistem merit dapat mendorong pelaksanaan percepatan kebijakan reformasi birokrasi. Menurut Agus Dwiyanto (2016:10-12) setidaknya terdapat lima manfaat sistem merit dikaitkan dengan reformasi birokrasi: pertama, sistem merit mendorong semua PNS untuk selalu meningkatkan kompetensinya agar kariernya bisa berkembang. Ketika penempatan seseorang dalam jabatan ditentukan oleh kompetensi, rekam jejak dan keunggulan kompetitif maka mereka akan terdorong untuk meningkatkan kompetensi dan membangun rekam jejak yang baik. Kedua, rekrutmen terbuka yang dilakukan secara transparan dan inklusif dapat mendorong mobilitas PNS antartingkat pemerintahan dan antarsektor. Ketiga, mengurangi politisasi dan komoditisasi jabatan birokrasi. Keempat, mengurangi mismatch antara kompetensi yang dimiliki PNS dengan jabatan yang diembannya. Kelima, meningkatkan akuntabilitas publik dari penempatan dan promosi PNS. Warga berhak dilayani oleh PNS yang kompeten dan terbaik dalam jabatan yang tersedia.

\section{Definisi Konsep dan Prinsip Sistem Merit}

Mencermati latar belakang penerapan sistem merit di berbagai negara yang termuat dalam berbagai kajian empirik, penulis menganggap penting untuk memahami definisi dan prinsip sistem merit. Berikut adalah perkembangan definisi dan prinsip sistem merit.

Sistem merit selalu dikaitkan dengan pola rekrutmen dan sistem promosi pada jabatan tertentu di suatu organisasi, baik di jabatan publik maupun jabatan-jabatan di sektor swasta. Tujuannya jelas yakni untuk memperoleh sumber daya manusia unggul yang memenuhi kualifikasi, kompetensi dan prestasi tertentu, sehingga keberadaannya bermanfaat tidak hanya bagi individu, organisasi saja, namun juga bagi masyarakat. Karena itu, tuntutan proses pelaksanaannya, mulai dari perencanaan, pelaksanaan dan penetapannya dilakukan secara kompetitif, terbuka, dan mempromosikannya sesuai dengan prestasi kerja bukan karena senioritas (Johnson \& Lewis, 2018; Poocharoen \& Brillantes, 2013; Zaman, 2015).

Secara prinsip, sistem merit tidak sekedar memilih secara kompeten, namun dalam proses rekrutmen dan promosi harus mampu menjamin lahirnya pemimpin yang anti korupsi 
sehingga mampu menjalankan tugas dan fungsinya secara profesional. Dalam penelitian yang menganalisis postur birokrasi dan efeknya terhadap korupsi di 52 negara, Carl Dahlström, Victor Lapuente, and Jan Teoreti membedakan antara birokrasi yang berorientasi pada kelembagaan/organisasi dengan birokrasi yang professional oriented. Birokrasi profesional memiliki spirit untuk mengurangi korupsi, tidak sekedar memilih orang yang yang lebih kompeten. Karena proses rekrutmen dan promosi setidaknya mampu memetakan SDM unggul, yang mampu memisahkan siapa yang memiliki kepentingan politik dan siapa yang profesional (Dahlström, Lapuente \& Teoreti, 2012; Johnson \& Lewis, 2018).

Selain itu, prinsip dasar yang juga penting dalam sistem merit adalah prestasi kerja. Sistem merit memfokuskan pada perbaikan atau peningkatan prestasi kerja (Daryanto, 2007; Mutia Ali et al., 2017).

Sistem merit didefinisikan sebagai sistem kepegawaian yang menempatkan prestasi kerja individu dalam mengelola tugas dan fungsinya, sehingga mereka berhasil dalam melayani masyarakat. Faktor utama seorang pegawai mampu melakukan pencapaian prestasi tertinggi karena beberapa faktor sebagai berikut: lingkungan yang kondusif atau mendukung, sistem penghargaan yang baik (rewards), kompetensi dan kontinuitas dalam proses pelayanan. Secara prinsip, sistem merit dipandang sebagai penunjukan, promosi, dan tindakan kepegawaian yang didasarkan atas kemampuan relatif karyawan dan kinerja pekerjaan dengan didukung oleh pengalaman praktik kerja yang baik. McCourt mendefinisikan merit dengan cara sederhana: merit menjadi cara yang tepat yang memberikan pernghargaan pada orang terbaik di posisi yang tepat. Atau dengan kata lain merit dianggap sebagai model rekrutmen dan promosi terbaik bagi orang dan pekerjaan yang terbaik untuk semua jenis pekerjaan (Mutia Ali et al., 2017).

\section{Pengalaman di Beberapa Negara: Kajian Empirik}

Studi tentang sistem merit telah dilakukan dari berbagai perspektif, baik sejarah, konsep, konteks, maupun konsekuensinya. Michael Young dalam bukunya yang sangat fenomenal "The Rise of the Meritocracy" menulis bahwa tahun 1870-an disebut sebagai era modern dihapusnya budaya patron dalam rekrutmen pegawai negeri sipil dan pemberlakuan sistem merit. Negara Inggris, Amerika, dan Jerman termasuk sebagai negara yang paling awal dikenal menerapkan sistem merit. Inggris memulai memperjuangkan penerapan sistem merit pada tahun 1853 dan baru pada tahun 1854, prinsip uji kompetensi dalam pegawai negeri diberlakukan. Tuntutan penerapan sistem merit dilatarbelakangi oleh semangat untuk mengatasi inefisiensi birokrasi karena gelombang korupsi dan nepotisme (Davis, 2006).

Sementara itu, The Paddleton Act of 1883 mengakhiri praktik pemberian pekerjaan negara federal berdasarkan hubungan politik atau hubungan pribadi yang mengabaikan kriteria merit dan baru pada tahun 1912, Kongres Amerika memberlakukan UU LloydLafolle yang mengatur tindakan pemindahan harus didasarkan pada merit dan sejak saat itu, sistem merit terus berkembang (USMSPB, 2020:1).

Di negara Jerman, menjadi contoh menarik yang dijadikan referensi utama para akademisi ketika berteori tentang bagaimana birokrasi Weberian bertransformasi dari abad kedelapan belas hingga dua puluh. Pegawai negeri sipil direkrut dan dipromosikan berdasarkan kualifikasi mereka tanpa mengacu pada pandangan pribadi atau politik mereka (Andersen, 2018).

Implementasi sistem merit berbeda antarnegara untuk tujuan yang tidak berbeda, yaitu membangun birokrasi yang kuat, loyal, dan kapabel. Setiap negara memiliki konsep dan definisi merit dan masing-masing menggunakan kebijakan dan alat yang berbeda untuk mengoperasionalisasikannya. Dalam studinya, Poocharoen dan Brillantes berpendapat 
bahwa implementasi merit di Asia utamanya untuk mengatasi masalah korupsi dan patronklien dalam rekrutmen dan promosi, sementara AS lebih kepada mengatasi isu intervensi politik (Poocharoen \& Brillantes, 2013).

Hal ini diperkuat oleh temuan Ruhil \& Camões, bahwa dinamika politik di Amerika memainkan peran signifikan terhadap penerapan sistem merit di negara-negara bagian. Di luar perkiraan, peran politik begitu besar dalam mendorong penerapan sistem merit dalam perjalanan sejarah prinsip ini di Amerika. Sehingga ditarik kesimpulan bahwa besarnya peran politik menguatkan Amerika dalam mengadopsi prinsip merit dan tetap menerapkannya secara komprehensif hingga saat ini (Ruhil \& Camões, 2003).

Jauh sebelumnya, Jogersen, Fairless dan Patton (1996) berpendapat bahwa implementasi sistem merit untuk memastikan bahwa layanan publik akan meningkat dengan merekrut pegawai yang berkualitas. Namun, tujuan baik tersebut perlu ditinjau dan disesuaikan secara berkala dengan memastikan bahwa sistem yang dirancang untuk mencapai tujuan tersebut terus bekerja dengan efektif ketika keadaan berubah (Lorna Jorgensen, Kelli Fairless, 1996).

Berdasarkan hasil analisis kuantitatif terhadap PNS dan calon PNS di Bangladesh, Zaman (2015) menyimpulkan hal yang sama bahwa rekrutmen berbasis sistem merit dapat menghindarkan korupsi. Bangladesh Civil Service (BSC) diilustrasikan awalnya sebagai sebuah surga hingga sistem merit hadir dalam proses rekrutmen secara terbatas oleh adanya kebijakan sistem quato untuk masyarakat "backward section".

Menurut Veran Stancetik (2020), berdasarkan hasil analisis terhadap perkembangan sistem merit dan efektivitasnya dalam administrasi negara-negara Balkan Barat, sistem merit belum efektif berjalan. Di sebagian besar negara Balkan Barat, Spoils System masih berjalan, meskipun undang-undang telah menetapkan sistem merit. Hal ini sebagai akibat terbukanya panggung politik melalui berbagai regulasi yang menimbulkan persaingan politik yang berefek pada sistem rekrutmen jabatan publik.

Dalam konteks kinerja organisasi, penerapan sistem merit pada pemilihan manajer publik akan menghasilkan serangkaian perbaikan dalam manajemen internal dan praktik organisasi- lebih daripada hasil yang diharapkan oleh institusi (Cortazár et.al, 2016). Cortazár et.al menyimpulkan bahwa manfaat lain tidak berwujud namun dapat dirasakan dari penggunaan sistem ini adalah tingkat legitimasi manajer yang lebih tinggi, serta komitmen yang lebih kuat untuk institusi. Pada penilaian kinerja pegawai, sistem merit menghilangkan bias penilaian kinerja yang selama ini terjadi dalam rangka pengambilan kebijakan lanjutan (Daryanto, 2007).

Bagaimana dengan penerapan sistem merit di Indonesia? Penelitian Meutia dkk (2017) menyimpulkan bahwa penerapan sistem merit di Indonesia, yaitu pada proses seleksi dan promosi PNS, tidak hanya untuk mewujudkan pemerintah yang bersih dari Korupsi, Kolusi, dan Nepotisme (KKN), namun sekaligus untuk memberikan pelayanan lebih baik kepada masyarakat, dan mewujudkan transparansi dan akuntabilitas pemerintah (Mutia Ali et al., 2017).

Di Indonesia, tantangan penerapan sistem merit tidak mudah. Pelaksanaan sistem merit melalui seleksi terbuka bagi pengisian Jabatan Pimpinan Tinggi Pratama (JPT Pratama) sampai dengan saat ini belum bisa menerapkan seluruh prinsip dari sistem merit (Noors, 2019). Bahkan pelaksanaan sistem merit masih dikaitkan dengan balas budi dan balas dendam (Ismail, 2019). Selama ini sistem merit sebenarnya telah dilaksanakan, namun banyak manipulasi yang disengaja. Proses pengangkatan calon pejabat dilakukan secara diam-diam yang tentu bertentangan dengan konsepsi ilmu (Thoha, 2018) dan tidak dilaporkan ke KASN sebagai prosedur dalam proses rekrutmen secara terbuka (Rachmawati, 
2018). Keahlian dan profesionalisme ditempatkan di urusan yang tidak penting sedangkan bagi pemegang kekuasaan berbeda, dimana jabatan bagi seseorang adalah sesuai persepsi dan keinginan pemegang kekuasaan.

Hasil evaluasi paruh waktu terhadap RPJMN 2010-2014 menunjukkan bahwa kendala yang dihadapi dalam pencapaian target RPJMN masih sangat berat. Kualitas birokrasi pemerintah belum mampu mendukung pemerintahan yang efektif dan efisien, SDM aparatur belum bekerja secara profesional, berintegritas dan bermental melayani. Salah satu faktor yang sulit dikendalikan adalah tekanan politik terhadap kinerja birokrasi masih kuat dan berpengaruh pada lemahnya independensi birokrasi (Bappenas, 2013).

Meskipun demikian, persoalannya bukan hanya tekanan politik atau rendahnya independensi birokrasi. Menurut Rachmawati (2018), ada beberapa faktor yang menyebabkan meritokrasi di Indonesia akan memakan waktu panjang, karena lima hambatan yang menghadang, sebagai berikut : (1) adanya keengganan pemerintah daerah baik provinsi maupun kabupaten/kota untuk melaporkan pengisian Jabatan Pimpinan Tinggi; (2) keterbatasan lembaga assessment center dan assessor yang terakreditasi; (3) masih terbatasnya panitia seleksi yang kompeten dan kredibel; (4) konflik kepentingan (conlict of interest) yang masih sering dijumpai dalam beberapa keputusan panitia seleksi di berbagai instansi pemerintah dan terakhir, (5) kurangnya kemampuan dan kesiapan instansi pemerintah untuk melaksanakan seleksi terbuka.

Kajian Pemetaan Penerapan Sistem Merit dalam Manajemen Aparatur Sipil Negara yang dilaksanakan oleh KASN (2018) mengonfirmasikan tentang berbagai fenomena menarik yaitu : (1) jumlah instansi pemerintah yang benar-benar siap menerapkan sistem merit masih belum terlalu banyak; (2) Kementerian dan Lembaga Pemerintah Non Kementerian (LPNK) lebih siap menerapkan sistem merit dibandingkan dengan pemerintah Provinsi; (3) Pemerintah Provinsi di Jawa lebih siap dalam menerapkan sistem merit jika dibandingkan dengan pemerintah provinsi di luar Jawa; dan (4) Pemerintah Provinsi di wilayah Timur Indonesia relatif tertinggal dibandingkan dengan Pemerintah Provinsi lainnya dalam menerapkan kebijakan sistem merit (KASN, 2018:vi).

Menurut kajian tersebut, hambatan yang dihadapi oleh instansi pemerintah dalam membangun sistem merit tidak hanya masalah keterbatasan dana, namun juga keterbatasan kemampuan para pengelola pegawai untuk menyiapkan berbagai prasyarat yang diperlukan. Di samping itu, komitmen Pejabat Pembina Kepegawaian (PPK) di masing-masing instansi untuk mewujudkan manajemen ASN yang berbasis sistem merit masih menjadi kendala. Karena itu, menurut KASN tantangan kedepan dalam membangun sistem merit, penting untuk diperhatikan : (1) Mendorong instansi untuk menyiapkan rencana strategis bidang SDM yang menjadi bagian dari rencana strategis instansi; (2) Membangun sistem pembinaan karier yang berkelanjutan, yang dimulai sejak mereka diterima menjadi pegawai sampai mereka mengakhiri masa jabatannya, agar dapat menjalankan tugasnya secara profesional; (3) Mengembangkan manajemen kinerja untuk memastikan masing-masing pegawai dapat mencapai target yang telah diturunkan dari visi, misi dan tujuan instansi; (4) Menyusun kebijakan penggajian, penghargaan yang dikaitkan dengan kinerja dan disiplin untuk menjadi reward and punishment yang efektif dalam mendorong kinerja serta membentuk budaya kerja yang lebih produktif; dan (5) Menyiapkan para calon pemimpin yang dibutuhkan instansi dalam jangka pendek maupun jangka panjang dengan membangun talent pool yang berkesinambungan melalui upaya peningkatan kapasitas pegawai secara konvensional maupun non-konvensional ( 


\section{HASIL DAN PEMBAHASAN}

\section{Beberapa Upaya Penerapan Sistem Merit}

Pada periode kepemimpinan selanjutnya, Adi Suryanto akhirnya terpilih menjadi pengganti Agus Dwiyanto. Adi Suryanto menjadi kepala LAN juga melalui proses seleksi terbuka. Setidaknya ada delapan peserta yang mendaftar dalam seleksi tersebut, yang terdiri dari dua orang dari internal LAN dan enam orang dari eksternal (kementerian/lembaga, pemerintah daerah, perguruan tinggi dan badan usaha milik Negara (lihat Tabel 1).

\section{Tabel 1.}

Pelaksanaan Seleksi Terbuka di Lingkungan Lembaga Administrasi Negara Tahun 2015-2020

\begin{tabular}{|c|c|c|c|c|c|c|}
\hline \multirow{2}{*}{ No. } & \multirow{2}{*}{ Seleksi Terbuka } & \multirow{2}{*}{ Tahun } & \multicolumn{2}{|c|}{ Jumlah Pelamar } & \multicolumn{2}{|c|}{$\begin{array}{c}\text { Hasil akhir (3 } \\
\text { Pelamar) }\end{array}$} \\
\hline & & & Internal & Eksternal & Internal & Eksternal \\
\hline 1. & $\begin{array}{l}\text { JPT Utama-Kepala } \\
\text { LAN }^{1)}\end{array}$ & 2015 & 2 & 6 & 2 & 1 \\
\hline \multirow[t]{2}{*}{2.} & $\begin{array}{l}\text { JPT Pratama }{ }^{2)} \\
\text { - } \quad \text { Kepala Pusat } \\
\text { Pembinaan Analis } \\
\text { Kebijakan }\end{array}$ & 2015 & 6 & - & 3 & - \\
\hline & $\begin{array}{l}\text { - Kepala Pusat Inovasi } \\
\text { Pelayanan Publik }\end{array}$ & & 8 & - & 3 & - \\
\hline 3. & $\begin{array}{l}\text { JPT Madya- Deputi } \\
\text { Bidang Kajian } \\
\text { Kebijakan }^{3)}\end{array}$ & 2016 & 9 & 1 & 2 & 1 \\
\hline \multirow[t]{4}{*}{4.} & $\begin{array}{l}\text { JPT Pratama } \\
\text { - Kepala Pusat Kajian } \\
\text { Desentralisasi dan } \\
\text { Otonomi Daerah }\end{array}$ & 2016 & 6 & - & 3 & - \\
\hline & $\begin{array}{l}\text { - Kepala Pusat Inovasi } \\
\text { Kelembagaan dan } \\
\text { Sumber Daya } \\
\text { Aparatur }\end{array}$ & & 7 & - & 3 & - \\
\hline & $\begin{array}{l}\text { - Kepala PKP2A I } \\
\text { LAN Jatinangor }\end{array}$ & & 9 & - & 3 & - \\
\hline & $\begin{array}{l}\text { - Ketua STIA LAN } \\
\text { Bandung }\end{array}$ & & 3 & - & 3 & - \\
\hline \multirow[t]{3}{*}{5} & JPT Pratama & 2018 & & & & \\
\hline & - $\quad$ Kepala Biro Umum & & 3 & 2 & 2 & 1 \\
\hline & $\begin{array}{l}\text { - Kepala Pusat Inovasi } \\
\text { Kelembagaan dan } \\
\text { Sumber Daya } \\
\text { Aparatur }\end{array}$ & & 6 & 4 & 3 & - \\
\hline
\end{tabular}




\begin{tabular}{|c|c|c|c|c|c|c|}
\hline \multirow[t]{2}{*}{ No. } & \multirow[t]{2}{*}{ Seleksi Terbuka } & \multirow[t]{2}{*}{ Tahun } & \multicolumn{2}{|c|}{ Jumlah Pelamar } & \multicolumn{2}{|c|}{$\begin{array}{l}\text { Hasil akhir (3 } \\
\text { Pelamar) }\end{array}$} \\
\hline & & & Internal & Eksternal & Internal & Eksternal \\
\hline \multirow{9}{*}{6.} & $\begin{array}{l}\text { Kepala Pusat Kajian } \\
\text { Desentralisasi dan } \\
\text { Otonomi Daerah }{ }^{5)}\end{array}$ & & 3 & 3 & 2 & 1 \\
\hline & JPT Madya & 2018 & & & & \\
\hline & - Sekretaris Utama ${ }^{6)}$ & & 3 & 2 & 3 & - \\
\hline & - Deputi Bidang & & 7 & - & 3 & - \\
\hline & Penyelenggaraan & & & & & \\
\hline & $\begin{array}{l}\text { Pengembangan } \\
\text { Kompetensi }\end{array}$ & & & & & \\
\hline & - Deputi Bidang & & 2 & 2 & 2 & 1 \\
\hline & Kajian dan Inovasi & & & & & \\
\hline & Manajemen ASN ${ }^{7)}$ & & & & & \\
\hline \multirow[t]{13}{*}{7} & JPT Pratama & 2019 & & & & \\
\hline & $\begin{array}{l}\text { - Kepala Biro Hukum } \\
\text { dan Hubungan }\end{array}$ & & 1 & 3 & & \\
\hline & Masyarakat ${ }^{7)}$ & & & & & \\
\hline & $\begin{array}{l}\text { - Kepala Pusat Data } \\
\text { dan Sistem Informasi } \\
\text { 8) }\end{array}$ & & - & 7 & & \\
\hline & - Kepala Pusat Kajian & & 5 & 2 & 3 & - \\
\hline & Kebijakan & & & & & \\
\hline & Administrasi Negara & & & & & \\
\hline & - Kepala Pusat & & 5 & 3 & 3 & - \\
\hline & Pengembangan & & & & & \\
\hline & Kompetensi Teknis & & & & & \\
\hline & dan Sosial Kultural & & & & & \\
\hline & Aparatur Sipil & & & & & \\
\hline & Negara ${ }^{10)}$ & & & & & \\
\hline
\end{tabular}

Keterangan:

1) Pelamar dari eksternal berasal dari Kementerian/Lembaga, Pemerintah Daerah, Perguruan Tinggi, BUMN

2) Pelamar dari eksternal berasal dari Kementerian/Lembaga,

3) Pelamar dari eksternal berasal dari Kementerian/Lembaga, Perguruan Tinggi

4) Pelamar dari eksternal berasal dari Kementerian/Lembaga.

5) Pelamar dari eksternal berasal dari Kementerian/Lembaga, Pemerintah Daerah.

6) Pelamar dari eksternal berasal dari Kementerian/Lembaga

7) Pelamar dari eksternal berasal dari Kementerian/Lembaga

8) Pelamar dari eksternal berasal dari Kementerian/Lembaga

9) Pelamar dari eksternal berasal dari Kementerian/Lembaga

10) Pelamar dari eksternal berasal dari Kementerian/Lembaga

Di era kepemimpinan Adi Suryanto, LAN banyak belajar dari pengalaman sebelumnya sehingga dalam penerapan sistem merit kian matang. Selain itu, tindak lanjut atas pelaksanaan sistem merit baik di kementerian/LPNK, pemerintah daerah kian masif. 
Kemungkinan ini terkait dengan dukungan kebijakan sistem merit. Momentum kesadaran institusi pemerintah untuk memperoleh pemimpin yang memenuhi kualifikasi, kompetensi dan prestasi kerja yang gemilang, dimanfaatkan LAN untuk terus membenahi sistem rekrutmen jabatan pimpinan tinggi.

Penerapan sistem merit di LAN dimulai sejak seleksi terbuka kepala LAN dimulai, tahun 2012. Rekrutmen secara terbuka jabatan pimpinan tinggi ini sebagai imbas kebijakan pengarusutamaan (mainstreaming) reformasi birokrasi di lingkungan kementerian PAN dan RB, yang menurut penilaian Agus Dwiyanto, para pejabat pimpinan tinggi dan staf di kementerian belum reform-minded. Menurutnya, sebagai kementerian yang memperoleh mandat untuk memimpin pelaksanaan reformasi birokrasi, semua orang di Kementerian PAN dan RB harus memiliki reform-minded. Untuk apa? Setidaknya ada tiga alasan: pertama, memastikan bahwa reformasi birokrasi dan nilai-nilai yang mendasarinya diinternalisasikan ke dalam nilai-nilai penting dan diterjemahkan dan visi dan misi Kementerian PAN dan RB. Kedua, menerjemahkan reformasi birokrasi dan nilai-nilainya ke dalam fungsi dan aktifitas kementerian. Ketiga, mereformasi struktur kementerian agar sesuai dengan misi dan mandat baru menjadi penggerak reformasi birokrasi (Dwiyanto, 2016:3).

Rekrutmen terbuka untuk pengisian jabatan pimpinan tinggi, saat itu, tentu menjadi sebuah gebrakan penting duet menteri dan wakil menteri PAN dan RB, yakni bapak Azwar Abubakar dan Eko Prasojo. Keduanya telah berhasil meletakkan landasan yang kuat, bukan hanya dalam pelembagaan prinsip merit, namun juga dalam membangun imparsialitas birokrasi dan aparaturnya. Menurut Agus Dwiyanto (2016:9-10), selama ini rekrutmen pejabat publik, terutama di daerah, amat ditentukan oleh nepotisme, kontribusi dalam pilkada, dan faktor-faktor subjektif lainnya. Peristiwa seperti ini terjadi secara masif di daerah. Sayangnya, saat itu pemerintah pusat belum memiliki instrumen yang efektif untuk menghentikan politisasi birokrasi dan aparaturnya. Baru setelah lahirnya Undang-Undang (UU) No. 5 Tahun 2014 Tentang ASN, pelaksanaan rekrutmen terbuka jabatan pimpinan tinggi tidak hanya memiliki basis legal yang kuat, tetapi juga memiliki dukungan akal sehat (Dwiyanto, 2016:13).

Langkah Azwar Abubakar yang berani ini patut diapresiasi karena melawan tradisi yang berlaku selama ini, dimana pengangkatan pejabat pimpinan tinggi, seolah-olah menjadi privilege dari menteri yang mengoordinasikannya. Azwar Abubakar telah membuat privilege yang dimilikinya, sangat mungkin calon yang terseleksi bukan orang yang dikenal dan diketahui karakternya. Bagi seorang Menteri, hal ini tidak mudah karena mereka pada umumnya cenderung memilih orang yang telah dikenal, memiliki loyalitas, afiliasi politik yang sama, dan pertimbangan subyektif lainnya (Dwiyanto, 2016:15).

Penerapan sistem merit di LAN mendapatkan momentumnya pasca Agus Dwiyanto menjadi kepala LAN, yang dilantik pada 21 Juni 2012. Dalam berbagai kesempatan Agus Dwiyanto mengatakan bahwa dirinya menyadari sepenuhnya reformasi di LAN juga harus bergulir. Menurutnya, reformasi birokrasi di LAN sangat mendesak dan penting untuk dilakukan, mengingat peran LAN sebagai sebuah institusi strategis (Dwiyanto, 2015:1). LAN sebagai sebuah knowledge institution yang mendapatkan mandat untuk mengembangkan administrasi negara dan meningkatan kompetensi SDM penyelenggara negara, memiliki peran strategis untuk berkontribusi dalam mencapai tujuan pembangunan aparatur negara. Namun dengan tugas dan fungsi yang diembannya, LAN membutuhkan kapasitas organisasi yang kuat untuk dapat berkontribusi secara signifikan dalam melaksanakan mandat tersebut. Terdapat banyak kelemahan, permasalahan dan aspek-aspek penting yang perlu menjadi perhatian bagi LAN yang berimplikasi pada kinerja LAN. 
Perubahan lingkungan strategis dan tantangan yang dihadapi membuat LAN perlu melakukan perubahan internal untuk dapat berkiprah lebih baik dan menjadi role model bagi institusi pemerintah dalam melakukan perubahan (Dwiyanto, 2015:3).

Catatan kritis Agus Dwiyanto itu sebenarnya pengulangan terhadap kritiknya saat masih menjadi akademisi. Dalam kritiknya Agus Dwiyanto mengatakan bahwa sebagai pusat kajian tentang administrasi publik, LAN telah terperangkap pada perspektifnya yang sempit, berjangka pendek, dan cenderung menghabiskan energinya untuk mengelola pelatihan penjenjangan, yang mungkin bagi para pejabatnya lebih menguntungkan daripada menjadikan dirinya sebagai think-tank untuk mendukung misi Kementerian PAN dan RB, termasuk melakukan kajian terhadap berbagai masalah strategis terkait dengan reformasi birokrasi. Karena itulah Agus Dwiyanto mengusulkan agar LAN segera meredefinisi visi dan misinya sebagai pusat pengembangan dan kajian administrasi publik yang terkemuka, bukan sebagai pusat pendidikan dan pelatihan penjenjangan seperti yang dilakukannya sekarang ini. Energi LAN yang terbatas semestinya lebih banyak dimanfaatkan untuk melakukan kajian terhadap masalah-masalah strategis dan menjadikan hasil kajiannya sebagai dasar untuk mengembangkan inovasi dalam pengelolaan birokrasi dan administrasi publik di Indonesia. Sedangkan redefinisi terhadap misi LAN akan sangat bermanfaat bagi LAN sendiri sebagai bagian terpenting dari engine of reform (Mariman Darto, 2013).

Lahirnya dukungan kebijakan pemerintah terkait pola dan sistem rekrutmen yang lebih terbuka dan kompetitif menjadikan LAN sebagai salah satu institusi yang tepat bagi caloncalon peserta. Sebagaimana Tabel 1 di atas, bahwa sebaran instansi dan jumlah peserta dari eksternal terus bertambah. Tidak hanya itu, pada jabatan strategis, LAN juga mengakomodir calon dari eksternal baik pada posisi Deputi (jabatan pimpinan tinggi madya), maupun kepala pusat (Jabatan pimpinan tinggi pratama).

Selain itu, komitmen pimpinan LAN dalam mengawal penerapan sistem merit juga dapat dilihat dalam melaksanakan berbagai ketentuan kebijakan yang ada. Setidaknya terdapat empat payung hukum yang dijadikan dasar dalam penerapan kebijakan sistem merit: Undang-Undang Nomor 5 Tahun 2014 Tentang Aparatur Sipil Negara (ASN); Peraturan Presiden Nomor 11 Tahun 2017 Tentang Manajemen Pegawai Negeri Sipil (PNS); Peraturan Menteri Pendayagunaan Aparatur Negara dan Reformasi Birokrasi Nomor 40 Tahun 2018 Tentang Pedoman Sistem Merit dalam Manajemen Aparatur Sipil Negara (ASN); dan Peraturan Ketua Komisi Aparatur Sipil Negara Nomor 5 Tahun 2017 Tentang Penilaian Mandiri Penerapan Sistem Merit dalam Manajemen Aparatur Sipil Negara (ASN) di Instansi Pemerintah. Tentu terdapat beberapa kebijakan lain seperti peraturan Menteri PAN dan RB dan berbagai surat edaran sebagai dasar teknis pelaksanannya.

Berdasarkan ketentuan Undang-Undang Nomor 5 Tahun 2014 tentang Aparatur Sipil Negara, sistem merit didefinisikan sebagai kebijakan dan manajemen ASN yang berdasarkan pada kualifikasi, kompetensi, dan kinerja secara adil dan wajar dengan tanpa membedakan latar belakang politik, ras, warna kulit, agama, asal usul, jenis kelamin, status pernikahan, umur, atau kondisi kecacatan. Sedangkan manajemen ASN adalah pengelolaan ASN untuk menghasilkan Pegawai ASN yang profesional, memiliki nilai dasar, etika profesi, bebas dari intervensi politik, bersih dari praktik korupsi, kolusi, dan nepotisme. Sesuai dengan ketentuan pasal 51 UU ASN, manajemen ASN diselenggarakan berdasarkan sistem merit, maka idealnya seluruh proses manajemen ASN akan menghasilkan ASN yang profesional, memiliki nilai dasar, etika profesi, bebas dari intervensi politik, bersih dari praktik korupsi, kolusi, dan nepotisme.

Hal ini sesuai dengan tujuan penerapannya yakni: (1) melakukan rekrutmen, seleksi, dan promosi berdasarkan kompetensi yang terbuka dan adil dengan menyusun perencanaan 
SDM Aparatur secara berkelanjutan; (2) memperlakukan pegawai ASN secara adil dan setara; (3) mengelola pegawai ASN secara efektif dan efisien; (4) memberikan remunerasi yang setara untuk pekerjaan-pekerjaan yang setara dengan memperhatikan hasil kerjanya; (5) memberikan penghargaan atas kinerja pegawai yang tinggi; (6) memberikan hukuman atas pelanggaran disiplin; (7) menjaga standar yang tinggi untuk integritas, perilaku, dan kepedulian untuk kepentingan masyarakat; (8) menerapkan pengisian jabatan dengan uji kompetensi sesuai standar kompetensi jabatan yang dipersyaratkan; (9) memberikan kesempatan untuk mengembangkan kompetensi kepada pegawai ASN; (10) melaksanakan manajemen kinerja pegawai untuk mencapai tujuan organisasi; (11) melindungi pegawai ASN dari intervensi politik dan tindakan kesewenang-wenangan ; dan (12) memberikan perlindungan kepada pegawai.

Jika disederhanakan, tujuan sistem merit adalah: pertama, merekrut ASN yang profesional dan berintegritas, serta menempatkan mereka pada jabatan-jabatan birokrasi pemerintah sesuai kompetensinya; kedua, mempertahankan ASN melalui pemberian kompensasi yang adil dan layak; ketiga, mengembangkan kemampuan ASN melalui bimbingan dan pelatihan dan keempat melindungi karir ASN dari politisasi dan kebijakan yang bertentangan dengan prinsip merit seperti nepotisme dan primordialisme.

Pencapaian terhadap tujuan sistem merit dalam manajemen ASN bergantung pada komitmen pemangku kepentingan, khususnya Pejabat Pembina Kepegawaian (PPK), Pejabat yang Berwenang, pejabat pengelola kepegawaian dan pegawai ASN benar-benar memegang prinsip-prinsip sistem merit. Sebagaimana tertuang dalam pasal 162 PP Nomor 11 Tahun 2017 bahwa pengembangan karier, pengembangan kompetensi, pola karier, mutasi, dan promosi merupakan manajemen karier PNS yang harus dilakukan dengan menerapkan prinsip sistem merit. Adapun prinsip-prinsip dalam sistem merit adalah sebagai berikut : (1) seluruh jabatan sudah memiliki standar kompetensi jabatan; (2) perencanaan kebutuhan pegawai sesuai dengan beban kerja; (3) pelaksanaan seleksi dan promosi dilakukan secara terbuka; (4) memiliki manajemen karier yang terdiri dari perencanaan, pengembangan, pola karier, dan rencana suksesi yang diperoleh dari manajemen talenta; (5) memberikan penghargaan dan mengenakan sanksi berdasarkan pada penilaian kinerja yang obyektif dan transparan; (6) menerapkan kode etik dan kode perilaku pegawai ASN; (7) merencanakan dan memberikan kesempatan pengembangan kompetensi sesuai hasil penilaian kinerja; (8) memberikan perlindungan kepada pegawai ASN dari tindakan penyalahgunaan wewenang; dan memiliki sistem informasi berbasis kompetensi yang terintegrasi dan dapat diakses oleh seluruh pegawai.

Selama menerapkan sistem merit, daya dukung kebijakan internal sangat dibutuhkan. Tentu ini ikhtiar penting yang menunjukkan komitmen LAN dalam menerapkan sistem merit. Beberapa kebijakan yang mendukung pelaksanaan sistem merit di LAN antara lain, 1). Peraturan LAN No. 26 Tahun 2017 tentang Katalog Kompetensi dan Standar Kompetensi Jabatan di Lingkungan LAN; 2). Perka LAN No. 3 Tahun 2018 tentang Pedoman Uji Potensi dan Uji Kelayakan Jabatan Fungsional di Lingkungan Lembaga Administrasi Negara; 3). Perka LAN No. 14 Tahun 2019 tentang Perubahan Perka LAN No. 3 Tahun 2018 tentang Pedoman Uji Potensi dan Uji Kelayakan JF di Lingkungan LAN; 4). Perka LAN No. 2 Tahun 2019 tentang Manajemen SDM yang Terintegrasi di Lingkungan LAN; 5). Perka LAN RI No 3 Tahun 2020 tentang Manajemen Talenta PNS di Lingkungan LAN; 6). Peraturan LAN RI No. 10 Tahun 2020 tentang Organisasi dan Tata Kerja Balai Layanan Pemetaan Kompetensi (18 Mei 2020).

Semangat LAN untuk menerapkan sistem merit di instansinya tentu bukan hanya pada bagaimana LAN melakukan rekrutmen terhadap jabatan pimpinan tinggi secara terbuka dan 
kompetitif, namun LAN menginginkan agar semua kriteria penilaian sistem merit benarbenar dijalankan, sehingga LAN dapat melaksanakan manajemen ASN secara mandiri. Ini dimungkinkan sesuai dengan ketentuan pasal 111 UU ASN. Menurut Pasal 111, bahwa ketentuan mengenai pengisian Jabatan Pimpinan Tinggi dapat dikecualikan pada Instansi Pemerintah yang telah menerapkan sistem merit dalam pembinaan Pegawai ASN dengan persetujuan KASN.

Berdasarkan hasil pemetaan penerapan sistem merit dalam manajemen aparatur sipil Negara (ASN) di Kementerian, Lembaga Pemerintah Non Kementerian dan Provinsi LAN masuk dalam kategori IV atau sangat baik, dengan nilai 357,5 dan indeks 0,89 (KASN, 2018). Ini berarti kinerja penerapan sistem meritnya sangat baik. Hal ini sesuai dengan Keputusan KASN No. 05/KEP.KASN/C/IV/2019 tentang Penerapan Sistem Merit dalam Manajemen Aparatur Sipil Negara di Lingkungan Lembaga Administrasi Negara.

Menurut Peraturan Menteri Pendayagunaan Aparatur Negara dan Reformasi Birokrasi No. 40 Tahun 2018 dan Peraturan KASN No. 5 Tahun 2017, penilaian penerapan sistem merit dilakukan dengan menggunakan metode penilaian mandiri (self assessment), dimana Tim Penilai Instansi yang dibentuk oleh PPK melaksanakan penilaian berdasarkan kriteria dan sub-kriteria yang telah ditetapkan KASN. Hasil penilaian kemudian disampaikan kepada PPK untuk kemudian disampaikan kepada Ketua KASN.

Sedangkan kategori penilaiannya adalah sebagai berikut: Kategori I (nilai 100-174), dengan indikator berwarna merah menunjukkan bahwa instansi dinilai 'BURUK'. Instansi dalam kategori ini masih perlu dibimbing intensif untuk dapat memenuhi persyaratan yang diharapkan dalam penerapan sistem merit manajemen ASN. Kategori II (nilai 175-249), dengan indikator berwarna kuning, menunjukkan bahwa instansi dinilai 'KURANG'. Instansi dalam kategori ini perlu dibimbing untuk melengkapi berbagai persyaratan sistem merit dalam manajemen ASN. Ketegori III (nilai 250-324), dengan indikator berwarna hijau, menunjukkan bahwa instansi dinilai 'BAIK'. Instansi dalam kateogri ini masih perlu menyempurnakan berbagai persyaratan penerapan sistem merit dalam manajemen ASN di instansinya, tetapi sudah dapat menerapkan seleksi terbatas dari talent pool dengan pengawasan KASN serta dievaluasi setiap tahun. Kategori IV (nilai 325-400), dengan indikator berwarna biru, menunjukkan bahwa instansi dinilai 'SANGAT BAIK'. Instansi dalam kategori ini menunjukkan bahwa sebagian besar persyaratan sudah dipenuhi dan sudah dapat diizinkan untuk menjalankan seleksi terbatas di instansinya melalui talent pool dan dievaluasi setiap dua tahun.

Tabel 2 berikut menunjukkan bahwa LAN telah memenuhi seluruh prasyarat sebagai lembaga yang menerapkan sistem merit. Pemenuhan seluruh prasarat itu mengacu Peraturan Menteri Pendayagunaan Aparatur Negara dan Reformasi Birokrasi Nomor 40 Tahun 2018 tentang Pedoman Sistem Merit dalam Manajemen Aparatur Sipil Negara (ASN) dan Peraturan Ketua Komisi Aparatur Sipil Negara Nomor 5 Tahun 2017 tentang Penilaian Mandiri Penerapan Sistem Merit dalam Manajemen Aparatur Sipil Negara (ASN) di Instansi Pemerintah. Tabel ini sekaligus menjawab pertanyaan bagaimana LAN menjawab kebutuhan pemenuhan standar penerapan sistem merit. Dari data ini tergambar bahwa penerapan sistem merit tidak mudah. 
Tabel 2.

Kriteria Penilaian Penerapan Sistem Merit di Lembaga Administrasi Negara

\begin{tabular}{|c|c|c|c|}
\hline No. & Kriteria Sistem Merit & $\begin{array}{c}\text { Check } \\
\text { List }\end{array}$ & Keterangan \\
\hline 1 & $\begin{array}{l}\text { Mempunyai rencana kebutuhan ASN } \\
\text { untuk } 5 \text { tahun yang dirinci menurut } \\
\text { jenis dan jenjang jabatan serta } \\
\text { disusun berdasarkan Analisa Jabatan } \\
\text { (Anjab) dan Analisa Beban Kerja } \\
\text { (ABK) dengan mempertimbangkan } \\
\text { pegawai yang memasuki masa } \\
\text { pensiun; }\end{array}$ & $\sqrt{ }$ & 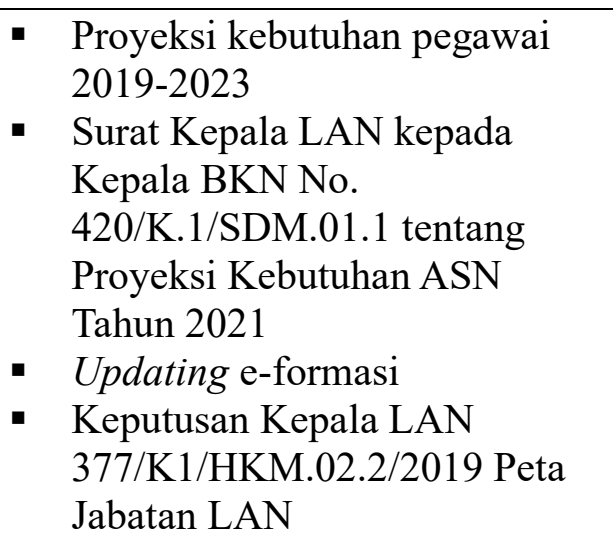 \\
\hline 2 & $\begin{array}{l}\text { Melakukan rekrutmen pegawai } \\
\text { secara terbuka dan kompetitif, baik } \\
\text { dari jalur CPNS, PPPK, dan juga dari } \\
\text { PNS yang berasal dari instansi lain }\end{array}$ & $\sqrt{ }$ & $\begin{array}{l}\text { - Pengumuman Nomor: } \\
\text { 3339/S.1/SDM.01.2 } \\
\text { Pelaksanaan Seleksi CPNS } \\
\text { LAN Tahun } 2018 \\
\text { - } \quad \text { Portal cpns.lan.go.id }\end{array}$ \\
\hline 3 & $\begin{array}{l}\text { Mempunyai kebijakan dan program } \\
\text { pengembangan karier yang dimulai } \\
\text { dengan pemetaan talenta, analisis } \\
\text { kesenjangan kompetensi, dan } \\
\text { kesenjangan kinerja, strategi dan } \\
\text { program untuk mengatasi } \\
\text { kesenjangan dan pembentukan talent } \\
\text { pool dan rencana suksesi }\end{array}$ & $\sqrt{ }$ & $\begin{array}{l}\text { Peraturan LAN Nomor } 26 \\
\text { Tahun } 2017 \text { Katalog } \\
\text { Kompetensi dan Standar } \\
\text { Kompetensi Jabatan } \\
\text { Peraturan Kepala LAN No. } 2 \\
\text { Tahun } 2019 \text { tentang } \\
\text { Manajemen Sumber Daya } \\
\text { Manusia yang Terintegrasi di } \\
\text { lingkungan LAN } \\
\text { Perka LAN RI No } 3 \text { Tahun } \\
2020 \text { tentang Manajemen } \\
\text { Talenta PNS di Lingkungan } \\
\text { LAN } \\
\text { HCDP (Human Capital } \\
\text { Development Program) LAN }\end{array}$ \\
\hline 4 & $\begin{array}{l}\text { Menerapkan manajemen kinerja, } \\
\text { yang dimulai dengan penetapan } \\
\text { target kinerja, evaluasi kinerja secara } \\
\text { berkala dengan menggunakan } \\
\text { metode yang obyektif, menganalisis } \\
\text { kesenjangan kinerja, dan mempunyai } \\
\text { strategi untuk mengatasinya }\end{array}$ & $\sqrt{ }$ & $\begin{array}{l}\text { Peraturan Kepala LAN No. } 14 \\
\text { Tahun } 2019 \text { tentang Perubahan } \\
\text { Perka LAN No. } 3 \text { Tahun } 2018 \\
\text { tentang Pedoman Uji Potensi } \\
\text { dan Uji Kelayakan JF di } \\
\text { Lingkungan LAN } \\
\text { - Profilling Pegawai }\end{array}$ \\
\hline 5 & $\begin{array}{l}\text { Mengaitkan kebijakan penggajian, } \\
\text { pemberian penghargaan, dan promosi } \\
\text { dengan kinerja dan disiplin }\end{array}$ & $\sqrt{ }$ & $\begin{array}{l}\text { Peraturan Lembaga } \\
\text { Administrasi Negara No. } 7 \\
\text { Tahun } 2012 \text { tentang Tunjangan } \\
\text { Kinerja Pegawai di Lingkungan } \\
\text { LAN }\end{array}$ \\
\hline
\end{tabular}




\begin{tabular}{|c|c|c|c|}
\hline No. & Kriteria Sistem Merit & $\begin{array}{c}\text { Check } \\
\text { List }\end{array}$ & Keterangan \\
\hline 6 & $\begin{array}{l}\text { Melaksanakan promosi, mutasi } \\
\text { secara obyektif dan transparan } \\
\text { didasarkan pada kesesuaian } \\
\text { kualifikasi, kompetensi dan kinerja } \\
\text { dengan memanfaatkan talent pool }\end{array}$ & Love & 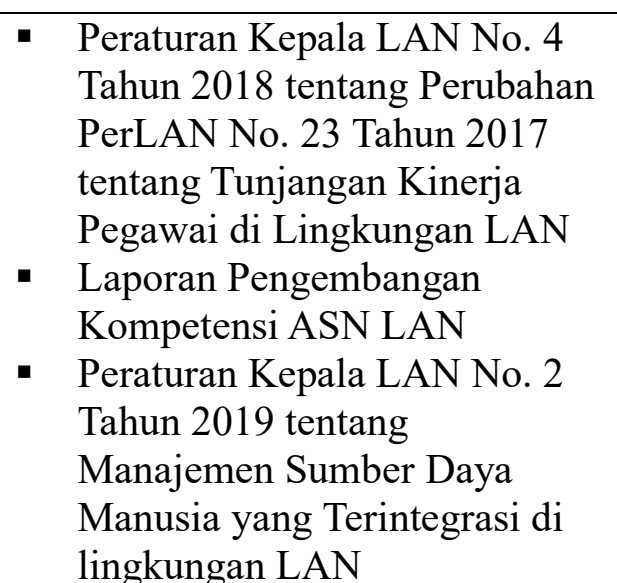 \\
\hline 7 & $\begin{array}{l}\text { Memberi perlindungan dan } \\
\text { pelayanan agar pegawai ASN dapat } \\
\text { melaksanakan tugas dengan baik }\end{array}$ & $\sqrt{ }$ & $\begin{array}{l}\text { Peraturan Kepala LAN Nomor } \\
5 \text { Tahun } 2015 \text { Kode Etik Bagi } \\
\text { Pegawai LAN }\end{array}$ \\
\hline 8 & $\begin{array}{l}\text { Mempunyai sistem pendukung } \\
\text { seperti sistem informasi kepegawaian } \\
\text { yang terintegrasi, assessment center, } \\
\text { dan aplikasi lainnya yang } \\
\text { mendukung pelaksanaan manajemen } \\
\text { ASN. }\end{array}$ & $\sqrt{ }$ & $\begin{array}{l}\text { - Sistem Informasi Kepegawaian } \\
\text { dan Tunjangan Kinerja Pegawai } \\
\text { (SIKTKP) } \\
\text { - } \quad \text { Assessment Center } \\
\text { - } \quad \text { SINIKTALA (Sistem } \\
\text { Elektronik Tata Laksana) }\end{array}$ \\
\hline
\end{tabular}

Konsekuensinya, sejak tahun 2019 LAN telah menerapkan sistem merit berbasis Talent Management. Tabel 3 berikut menunjukkan rekrutmen jabatan pimpinan tinggi pratama atau setingkatnya pada tiga jabatan yakni: Kepala Pusat Inovasi Administrasi Negara, Kepala Pusat Pengembangan Kader ASN dan Ketua Sekolah Tinggi Ilmu Administrasi LAN Jakarta.

Tabel 3.

Kelompok Rencana Suksesi (Talent Mapping) LAN Tahun 2019

\begin{tabular}{|c|c|c|c|c|c|}
\hline \multirow[t]{2}{*}{ No. } & \multirow[t]{2}{*}{ Seleksi Terbuka } & \multicolumn{2}{|c|}{ Jumlah Pelamar } & \multicolumn{2}{|c|}{$\begin{array}{l}\text { Hasil Akhir } \\
\text { (3 Pelamar) }\end{array}$} \\
\hline & & Internal & Eksternal & Internal & Eksternal \\
\hline \multirow[t]{3}{*}{1.} & Kepala Pusat & & & & \\
\hline & Inovasi & 5 & - & 3 & - \\
\hline & Administrasi Negara & & & & \\
\hline \multirow[t]{3}{*}{2.} & Kepala Pusat & & & & \\
\hline & Pengembangan & 6 & - & 3 & - \\
\hline & Kader ASN & & & & \\
\hline 3. & $\begin{array}{l}\text { Ketua STIA LAN } \\
\text { Jakarta *) }\end{array}$ & & 1 & - & 1 \\
\hline
\end{tabular}

Keterangan :

*) Surat permohonan kepada Kementerian Dalam Negeri c.q. IPDN 


\section{Alasan Penerapan Sistem Merit di LAN}

Lahirnya UU No. 5 Tahun 2014 tentang ASN dilatarbelakangi oleh sebuah harapan besar bahwa pembangunan ASN yang berintegritas, profesional, netral dan bebas dari intervensi politik, bersih dari praktik korupsi, kolusi, dan nepotisme, serta mampu menyelenggarakan pelayanan publik bagi masyarakat sangat perlu. Keberadaannya sangat diperlukan untuk merespon Visi Indonesia 2045. Sistem merit sebagai kebijakan dan manajemen ASN yang berdasarkan pada kualifikasi, kompetensi, dan kinerja secara adil dan wajar dengan tanpa membedakan latar belakang politik, ras, warna kulit, agama, asal usul, jenis kelamin, status pernikahan, umur, atau kondisi kecacatan menjadi pendekatan yang tepat untuk merespon mandat UU ASN tersebut.

Sebagai sebuah knowledge institution yang mendapatkan mandat untuk mengembangkan administrasi negara dan meningkatkan kompetensi SDM penyelenggara negara, LAN memiliki peran strategis untuk berkontribusi dalam mencapai visi Indonesia tersebut melalui pembangunan aparatur Negara. Berbagai pengalamannya dalam menerapkan sistem merit sangat penting untuk disosialisasikan dan didiseminasikan. Sebagai jawaban atas tiga pertanyaan penelitian ini, maka berikut disampaikan tiga kesimpulan penting yang perlu digarisbawahi:

Pertama, setidaknya terdapat enam alasan kenapa LAN menerapkan sistem merit : (1) LAN berharap dalam proses rekrutmen pejabat tinggi tidak ada korupsi, kolusi dan nepotisme $(\mathrm{KKN})$; (2) tidak ada politisasi birokrasi, sehingga prosesnya dapat berjalan secara netral untuk menghasilkan kualitas pemimpin yang kompeten dan kaya akan rekam jejak yang baik; (3) sistem merit diharapkan mampu menjawab problem ketidakefisienan (smashed the inefficiency) yang terjadi pada penerapan sistem administrasi negara yang lama, dimana korupsi dan nepotisme terjadi; (4) mempertimbangkan profesionalisme aparatur, karena sistem merit mampu merekrut pegawai dengan kemampuan dan kompetensi unggul lebih penting dan bermanfaat bagi organisasi dari pada pilihan dan pertimbangan senioritas dan usia; (5) menciptakan dan membangun budaya persaingan yang kompetitif sebagai bekal menghadapi tantangan masa depan; dan (6) karena sistem merit dapat mendorong pelaksanaan percepatan kebijakan reformasi birokrasi LAN.

Hasil wawancara terhadap pejabat pimpinan tinggi madya dan utama di LAN menunjukkan bahwa sistem merit merupakan lagkah transformatif tata kelola pembinaan ASN. Tahapannya dimulai dari sistem rekrutmen hingga pengangkatan dalam jabatan. Aspek yang dipertimbangkan sebagai dasar merit adalah kualifikasi, kompetensi, dan kinerja. Menurut kepala LAN, ketiga aspek dalam sistem merit ASN ini membawa pola perubahan pembinaan manajemen ASN yang selama ini berada pada konsep comfort zone ke arah competitive zone. "Jika pada ketentuan sebelumnya pengangkatan dalam jabatan mensyaratkan masa kerja (pangkat/golongan) tertentu yang bisa ikut pengisian jabatan, maka pola pembinaan manajemen PNS dalam PP No. 11 Tahun 2017 ini tidak akan memberlakukan lagi syarat pangkat/golongan ruang dalam pengangkatan ke dalam jabatan".

Di bagian lain, salah satu pejabat pimpinan tinggi mengatakan bahwa titik berat PP No. 11 Tahun 2017 tentang Manajemen ASN adalah kualifikasi dan kompetensi jabatan yang dimiliki masing-masing individu pemangku jabatan. Ini akan memicu dan memacu kompetensi terbuka bagi para ASN. 


\section{Langkah Penerapan Sistem Merit}

Lantas bagaimana LAN memulai penerapan sistem merit? LAN menerapkan sistem merit, dengan merekrut jabatan tinggi secara kompetitif dan terbuka tidak secara langsung. Karena penerapan sistem merit membutuhkan transformasi organisasi terlebih dahulu. Kenapa LAN membutuhkan transformasi organisasi?

Transformasi organisasi diperlukan LAN merupakan upaya penguatan organisasi LAN yang dilakukan sebagai upaya untuk menemukan dan menafsirkan kembali peran-peran strategis yang akan dilakukan oleh LAN pada masa mendatang berdasarkan situasi dan konteks aktual, dengan semangat yang sama seperti ketika LAN pertama dibentuk pada tahun 1957. Langkah transformasi organisasi yang berjalan di LAN RI mulai menemukan jalannya dan pada tahun 2012 terjadi titik balik dalam sejarah struktur organisasi LAN. Mulai tahun tersebut dilakukan perubahan organisasi yang diarahkan pada perubahan dari fragmented structure menuju consolidated structure.

Struktur lama LAN disusun dengan mendasarkan pada Peraturan Pemerintah No.103 tahun 2001 tentang Kedudukan, Tugas, Fungsi, kewenangan, Susunan Organisasi, Lembaga Pemerintah Non Departemen. Berdasarkan peraturan ini, LAN terdiri dari lima kedeputian yaitu: 1) Deputi bidang Kajian Kinerja Kelembagaan dan Sumber Daya Aparatur; 2) Deputi bidang Kajian Manajemen Kebijakan dan Pelayanan; 3) Deputi Bidang Litbang Administrasi Pembangunan; 4) Deputi Bidang Pembinaan Diklat Aparatur; 5) Deputi Bidang Diklat SPIMNAS. Pelaksanaan misi LAN dengan struktur organisasi lama, dimana fungsi Pendidikan dan Pelatihan dilaksanakan oleh dua deputi dan fungsi kajian dan litbang dilaksanakan oleh tiga deputi dinilai akan semakin memperkuat fragmentasi dalam struktur organisasi LAN. Koordinasi kebijakan serta pelaksanan tugas akan semakin sulit untuk dioptimalkan yang berujung pada lemahnya sinergi antar unit dalam pencapaian tujuan organisasi. Kondisi ini, mendesak untuk diatasi dengan melakukan penyederhanaan struktur organisasi dimana satu kediklatan ditangani satu deputi, fungsi kajian dan litbang ditangani satu deputi, serta fungsi inovasi ditangani oleh satu deputi. Gagasan dasar yang ingin diwujudkan adalah agar struktur organisasi LAN menjadi struktur yang terkonsolidasi. Dengan demikian, keruwetan terkait koordinasi kebijakan dan implementasi dapat diminimalisasi ke level terendah (Dwiyanto, 2015:6).

Pada tahun 2013 terbit Peraturan Presiden Nomor 57 Tahun 2013 yang menjadi dasar hukum bagi terbentuknya struktur baru LAN. Sesuai dengan Peraturan Presiden Nomor tersebut, Lembaga Administrasi Negara adalah lembaga nonkementerian yang berada di bawah dan bertanggung jawab kepada Presiden melalui Menteri Pendayagunaan Aparatur Negara dan Reformasi Birokrasi (PAN-RB). Dalam melaksanakan tugas tersebut, LAN menyelenggarakan fungsi antara lain: (a). Pengkajian dan penyusunan kebijakan nasional tertentu di bidang administrasi negara; (b). Pengkajian administrasi negara di bidang kebijakan dan reformasi administrasi, desentralisasi dan otonomi daerah, sistem administrasi negara, dan hukum administrasi negara; (c). Pengembangan inovasi administrasi di bidang tata pemerintahan, pelayanan publik, serta kelembagaan dan sumber daya aparatur; (d). Pemberian fasilitas dan pembinaan terhadap kegiatan instansi Pemerintah di bidang administrasi negara; dan (e) Pembinaan, penjaminan mutu, dan penyelenggaraan pendidikan dan pelatihan sumber daya aparatur Negara (Dwiyanto, 2015:7).

Setelah itu gelombang rekrutmen jabatan pimpinan tinggi dilakukan. Dimulai dari kocok ulang para Deputi yang sebenarnya masih menjabat, namun karena kebutuhan transformasi mereka diminta untuk mengikuti tahapan rekrutmen jabatan secara terbuka. Karena jumlah kedeputiannya terbatas, maka eks deputi lama ditambah dengan para jabatan pimpinan tinggi pratama yang ada di LAN dan dari berbagai unsur eksternal terlibat dalam 
proses lelang jabatan ini, untuk memperebutkan tiga deputi yakni: Deputi Kajian, Deputi Pendidikan dan Pelatihan dan Deputi Inovasi Administrasi Negara.

Prosesnya dilakukan secara transparan, kompetitif dan terbuka, dan akhirnya terpilih wajah baru yang masih muda, sehingga senioritas, batasan usia menjadi tidak diperlukan lagi (Andersen, 2018; Daryanto, 2007; Davis, 2006; Johnson \& Lewis, 2018; Mutia Ali et al., 2017; Poocharoen \& Brillantes, 2013; Zaman, 2015; Dwiyanto, 2016:10-12). Proses pengisian jabatan pimpinan tinggi terus berjalan hingga periode terakhir Agus Dwiyanto. Meskipun secara tegas aturan pelaksananya terbatas, namun Agus Dwiyanto terus melakukan rekrutmen terbuka untuk mengisi jabatan pimpinan tinggi pratama dalam rangka mengisi jabatan yang kosong karena perubahan struktur organisasi yang baru.

\section{E. PENUTUP}

Ada beberapa kesimpulan yang dapat dipetik, terutama dalam merespons tiga pertanyaan penelitian ini, sebagai berikut:

Pertama, apa yang telah dilakukan LAN? Pemenuhan seluruh kriteria dan sub kriteria penilaian mulai dari aspek perencanaan kebutuhan jenjang jabatan, rekrutmen terbuka dan kompetitif, menerapkan manajemen kinerja secara terukur dan objektif, menerapkan kebijakan reward and punishment secara konsisten, melaksanakan promosi, mutasi secara transparan dan objektif, memberikan perlindungan dan pelayanan pegawai, sistem kepegawaian yang terintegrasi, assessment center dan berbagai aplikasi lainnya tentu tidak mudah. Namun LAN mampu melakukannya dan dapat memenuhi seluruh prasyarat yang dibutuhkan sesuai dengan delapan kriteria penilaian sistem merit yang diatur dalam kebijakan yang berlaku. Inilah jawaban atas pertanyaan tersebut.

Kedua, mengapa LAN menerapkan sistem merit? Alasan utamanya adalah percepatan reformasi birokrasi di LAN. Salah satu langkah terpentingnya adalah dengan menerapkan sistem merit yang berbasis kualifikasi, kompetensi dan prestasi kerja. Ketiganya mampu mendorong profesionalisme ASN sebagaimana mandat UU No. 5 Tahun 2014 tentang Aparatur Sipil Negara.

Ketiga, terdapat beberapa langkah penting sebagai tonggak menuju penerapan sistem merit: (1) Komitmen dan konsistensi dalam menerapkan standar kebijakan yang diatur dalam ketentuan perundang-undangan. Ini adalah kunci, apakah memang sistem merit bias dijalan secara konsisten atau tidak; (2) dukungan dari seluruh stakeholders baik internal dan eksternal sangat penting. Karena sistem merit bukan hanya urusan internal LAN namun menyangkut berbagai pihak. Kita membutuhkan ekosistem atau lingkungan yang mendukung. Resistensi selalu ada. Namun, kita juga harus memahami bahwa mendapatkan SDM aparatur unggul dan berdaya saing juga penting dalam mendukung visi organisasi dan pelayanan publik; (3) kekuatan tim internal sangat penting untuk menyukseskan sistem merit di LAN. Pengembangan kompetensi di internal melalui LAN Corporate University menjadi kata kunci.

Meskipun demikian, karena LAN mendapatkan pengecualian dalam menerapkan berbagai ketentuan terkait sistem merit, sebagaimana ketentuan dalam pasal 111 UU ASN, maka beberapa saran penting untuk dilakukan, antara lain: pertama, melakukan perbaikan secara terus menerus berbagai langkah penerapan sistem merit yang dinilai lemah, apalagi feedback dari pihak eksternal akan membantu LAN dalam menjaga konsistensi dalam penerapan sistem merit. Kedua, membangun corporate culture internal secara kontinum agar setiap pegawai tidak cenderung resisten terhadap perubahan. Ketiga, membangun kesadaran bersama bahwa untuk masuk ke dalam kelompok rencana suksesi (talent mapping) membutuhkan pengembangan kompetensi diri secara terus menerus dan tidak hanya 
berpangku tangan atau menunggu dipanggil untuk pengembangan. Membangun kesadaran yang demikian ini tidak bisa sekali, namun kedepan perlu lebih terencana.

\section{F. UCAPAN TERIMA KASIH}

Kami memberikan penghargaan dan mengucapkan terimakasih kepada: Siti Zakiyah, Awan Hari Murtiadi, Yudiantati Syafitri, Andi Wahyudi, Kemal Hidayah, Rustan Amarullah, dan Fani Heru Wismono atas bantuan data dan informasi serta sumbangan pemikirannya.

\section{DAFTAR PUSTAKA}

Andersen, D. D. E. (2018). Does Meritocracy Lead to Bureaucratic Quality? Revisiting the Experience of Prussia and Imperial and Weimar Germany. Social Science History, 42(2), 245-268. https://doi.org/10.1017/ssh.2017.48

Baimenov, Alikhan and Max Everest-Phillips (2015). Meritocracy for Public Service Excellence. UNDP Global Centre for Public Service Excellence (Singapore) and Regional Hub of Civil Services in Astana (Kazakhstan).

Bappenas. (2013). Buku Evaluasi Paruh Waktu RPJMN 2010-2014. Badan Perencanaan Pembangunan Nasional.

Carlos, Cortazar Juan. Fuenzalida Javier., and L. M. (2016). Merit-based Selection of Public Managers: Better Public Sector Performance? An Exloratory Study (Issue September). Inter-American Development Bank.

Dahlström, Carl. Victor Lapuente., and J. T. (2012). The Merit of Meritocratization: Politics, Bureaucracy, and the Institutional Deterrents of Corruption. Political Research Quarterly, 65(3), 656-668. http://www.jstor.org/stable/41635262

Darto, Mariman. (2013). Kepemimpinan Transformasional dalam Konteks Perubahan Organisasi di Lembaga Administrasi Negara. Jurnal Borneo Administrator, 9(3), 239-264. https://doi.org/10.1108/09534819910263631

Daryanto, A. (2007). Merit System Dalam Manajemen Pegawai Negeri Sipil. Kebijakan Dan Manajemen PNS, IV, 1-13. https://doi.org/10.1084/jem.50.6.713

Davis, J. (2006). Meritocracy in the civil service, 1853-1970. Political Quarterly, 77(1), 27 35. https://doi.org/10.1111/j.1467-923X.2006.00778.x

Dul, J., \& Hak, T. (2007). Case Study Methodology in Business Research. Elsevier Ltd. https://doi.org/10.4324/9780080552194

Dwiputrianti, Septiana. (2018). Challenges with Implementation of the Merit System in the Open Recruitment of Government High Positions: The Case in Indonesia. Advances in Social Science, Education and Humanities Research, Volume 191. Asian Association for Public Administration Annual Conference (AAPA 2018). Atlantis Press.

Dwiyanto, Agus. (2016). Memimpin Perubahan di Birokrasi Pemerintah: Catatan Kritis Seorang Akademisi. Yogyakarta: Gadjah Mada University Press.

Dwiyanto, Agus. (2015). Memorandum Akhir Jabatan Kepala LAN RI 2012-2015. Jakarta: LAN RI. Hal.1.

Hak, J. D. T. (2008). Case Study Methodology in Business Research (First Edit). Elsevier Ltd.

Ismail, Nurwita. (2019). Merit System dalam Mewujudkan Transparansi Pembinaan Karir Aparatur Negara. $A l^{\prime} A d l, X(1)$

Johnson, T., \& Lewis, G. B. (2018). Inspecting the Merit System's "Pivotal Idea": Does Competitive Examination Increase the Qualifications and Quality of the $U . S$. 
Federal Service? https://doi.org/10.1177/0734371X18794808

Jorgensen, Lorna., Kelli Fairless., and W. D. P. (1996). Underground Merit Systems and the Balance Between Service and Compliance. Review of Public Personnel Administration, 16(2), 5-20. https://doi.org/10.1177/0734371X9601600202

KASN. (2018). Pemetaan Penerapan Sistem Merit dalam Manajemen Aparatur Sipil Negara (ASN) (Edisi Pert). Komisi Aparatur Sipil Negara.

Lutfi, A. F., Zainuri, Z., \& Diartho, H. C. (2020). Dampak Korupsi Terhadap Pertumbuhan Ekonomi: Studi Kasus 4 Negara di ASEAN. E-Journal Ekonomi Bisnis dan Akuntansi, 7(1), 30. https://doi.org/10.19184/ejeba.v7i1.16482

Meyrina, Rr. Susana Andi. (2016). Implementasi Peningkatan Kinerja Melalui Merit system Guna Melaksanakan Undang-Undang aparatur Sipil Negara No. 5 Tahun 2014 di Kementerian Hukum dan HAM. Jurnal Ilmiah Kebijakan Hukum (JIKH), 10(2), 175 $-186$

Mudjiyanto, B. (2018). Tipe Penelitian Eksploratif Komunikasi. Jurnal Studi Komunikasi Dan Media, 22(1), 65. https://doi.org/10.31445/jskm.2018.220105

Mutia Ali, D., Prasojo, E., \& Jannah, L. M. (2017). The Transformation of Merit System in Indonesian Civil Servant Promotion System. International Journal of Management and Administrative Sciences (IJMAS), 5(04), 20-28. www.ijmas.orgwww.ijmas.org

Noors, Adima Insan Akbar. (2019). Pengarusutamaan Manajemen Talenta dalam Tata Kelola MSDM Birokrasi Indonesia. Jurnal Ilmu Pemerintahan Suara Khatulistiwa $(J I P S K), 4(2)$.

Poocharoen, O. O., \& Brillantes, A. (2013). Meritocracy in Asia Pacific: Status, Issues, and Challenges. Review of Public Personnel Administration, 33(2), 140-163. https://doi.org/10.1177/0734371X13484829

Prasojo, Eko. (2010). Reformasi Kepegawaian Indonesia: Sebuah Review dan Kritik. Jurnal Kebijakan dan Manajemen PNS, 4(1)

Presiden Republik Indonesia. (2020). Narasi Rencana Pembangunan Jangka Menengah Nasional Tahun 2020-2024.

Rachmawati, Tutik. (2018). Jalan Panjang Mewujudkan Meritokrasi di Indonesia. Retrieced from http://unpar.ac.id/jalan-panjang-mewujudkan-meritokrasi-di-indonesia/

Ruhil, A. V. S., \& Camões, P. J. (2003). What Lies Beneath: The Political Roots of State Merit Systems. Journal of Public Administration Research and Theory, 13(1), 2742. https://doi.org/10.1093/jpart/mug006

Stancetic, Veran. (2020). Spoils System Is Not Dead: The Development and Effectiveness of the Merit System in Western Balkans. Croatian and Comparative Public Administration (CCPA), 20(3), 415-438

Thoha, M. (2018). Sistem Merit dalam Pemerintahan. Harian Kompas

USMSPB. (2020a). U.S. Merit Systems Protection Board Strategic Plan for Fiscal Year 2020 - 2024. USMSPB.

USMSPB. (2020b). United States Merit Systems Protection Board Strategic Plan for FY 2020-2024. U.S. Merit Systems Protection Board. www.mspb.gove

Wijaya, Andy Fefta dkk. (2019). Perspective Merit System On Placement Regulation Of High Level Official Civil Servants (A Case Study Of Placement Civil Servants In Local Government On Palembang). HOLISTICA, 10(2), 187-206.

Zaman, M. S. (2015). Merit-Based Recruitment: The Key To Effective Public Administration In Bangladesh. Journal of Public Administration and Governance, 5(3), 96. https://doi.org/10.5296/jpag.v5i3.8216 